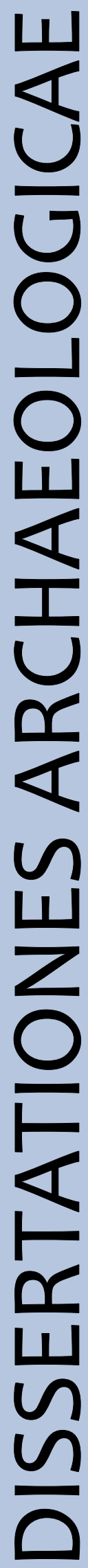

ex Instituto Archaeologico Universitatis de Rolando Eötvös nominatae
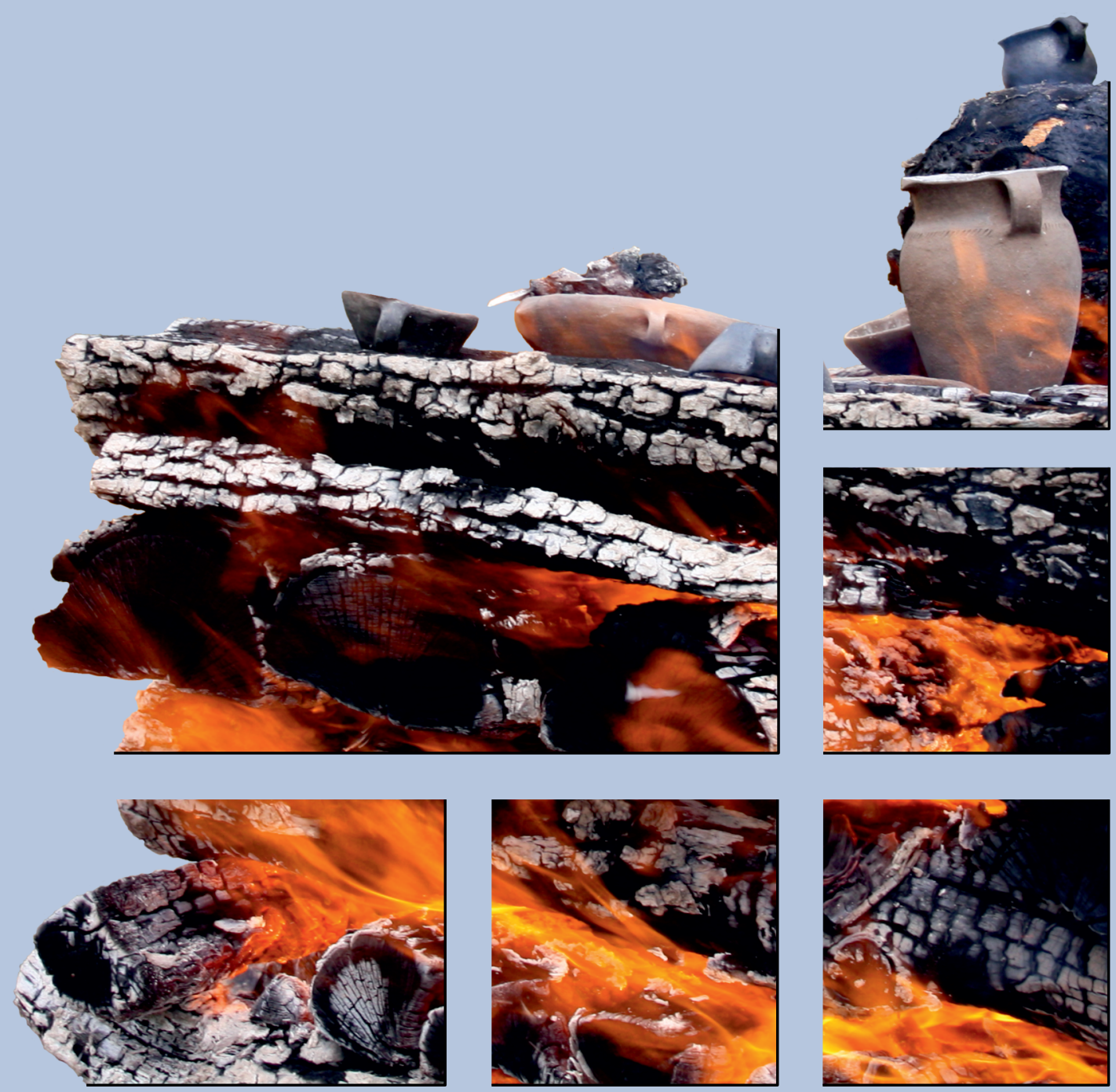

$$
\text { Ser。 3. No } 0_{0} \sigma_{0} \mid 2018
$$




\section{Dissertationes Archaeologicae ex Instituto Archaeologico}

Universitatis de Rolando Eötvös nominatae Ser. 3. No. 6.

Budapest 2018 


\section{Dissertationes Archaeologicae ex Instituto Archaeologico}

Universitatis de Rolando Eötvös nominatae Ser. 3. No. 6.

Editor-in-chief:

DÁvid BARTUS

Editorial board:

LÁsZló BARTOSIEWICZ

LÁSZLÓ BORHY

ZOLTÁN CZAJLIK

ISTVÁN FELD

GÁBOR KALLA

PÁL RACZKY

MiKLÓS SZABÓ

Tivadar Vida

Technical editor:

GÁBOR VÁcZI

Proofreading:

ZsófIA KondÉ

SzILVIA BARTUS-SzÖLLősI

Aviable online at http://dissarch.elte.hu

Contact: dissarch@btk.elte.hu

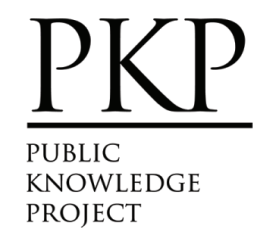

๑ E Eötvös Loránd University, Institute of Archaeological Sciences

Layout and cover design: Gábor Váczi

Budapest 2018 


\section{CONTENTS}

Zsolt Mester

In memoriam facques Tixier (1925-2018)

\section{ARTICLES}

Katalin SEBőK

On the possibilities of interpreting Neolithic pottery - Az újkökori kerámia értelmezési lehetőségeiről

András FüZESI - Pál RACZKY

Öcsöd-Kováshalom. Potscape of a Late Neolithic site in the Tisza region

Katalin SEBőK - Norbert FARAgó

Theory into practice: basic connections and stylistic affiliations of the Late Neolithic settlement at Pusztataskony-Ledence 1

Eszter Solnay

Early Copper Age Graves from Polgár-Nagy-Kasziba

László GuCsi - Nóra Szabó

Examination and possible interpretations of a Middle Bronze Age structured deposition

Kristóf FÜLÖP

Why is it so rare and random to find pyre sites? Two cremation experiments to understand the characteristics of pyre sites and their investigational possibilities

Gábor János TARBAY

"Looted Warriors" from Eastern Europe

Péter MogYoRós

Pre-Scythian burial in Tiszakürt

Szilvia JoHÁczi

A New Method in the Attribution? Attempts of the Employment of Geometric Morphometrics in the Attribution of Late Archaic Attic Lekythoi 
The Roman aqueduct of Brigetio

Lajos JuHÁsz

A republican plated denarius from Aquincum

Barbara HAJDU

Terra sigillata from the territory of the civil town of Brigetio

Krisztina HoppÁL - István VIDA - Shinatria AdHityatAma - Lu Yahui 461

'All that glitters is not Roman'. Roman coins discovered in East Java, Indonesia.

A study on new data with an overview on other coins discovered beyond India

\section{FIELD REPORTS}

Zsolt MESTER - Ferenc CSERPÁK - Norbert FARAGÓ

Preliminary report on the excavation at Andornaktálya-Marinka in 2018

Kristóf FÜLÖP - Denisa M. LÖNHARDT - Nóra SZABÓ - Gábor VÁcZI

Preliminary report on the excavation of the site Tiszakürt-Zsilke-tanya

Bence Simon - Szilvia JohÁcZI - Zita KIS

Short report on a rescue excavation of a prehistoric and Árpádian Age site near Tura

(Pest County, Hungary)

Zoltán CzAJlik - Katalin NovinszKi-Groma - László RupNIK - András BöDőcs - et al. 527

Archaeological investigations on the Süttö plateau in 2018

Dávid BARTus - László BORHY - Szilvia JoHÁczi - Emese SzÁMADó

Short report on the excavations in the legionary fortress of Brigetio (2017-2018)

Bence Simon - Szilvia JoháczI

Short report on the rescue excavations in the Roman Age Barbaricum near Abony

(Pest County, Hungary)

Szabolcs Balázs NAGY

Recent excavations at the medieval castle of Bánd 


\section{Thesis Abstracts}

Rita JENEY

Lost Collection from a Lost River: Interpreting Sir Aurel Stein's "Sarasvatī Tour" in the History of South Asian Archaeology

István VIDA

The Chronology of the Marcomannic-Sarmatian wars. The Danubian wars of Marcus Aurelius in the light of numismatics

Zsófia MASEK

Settlement History of the Middle Tisza Region in the $4^{\text {th }}-6^{\text {th }}$ centuries AD.

According to the Evaluation of the Material from Rákóczifalva-Bagi-földek 5-8-8A sites

Alpár Doвоs

Transformations of the human communities in the eastern part of the Carpathian Basin between the middle of the $5^{\text {th }}$ and $7^{\text {th }}$ century. Row-grave cemeteries in Transylvania, Partium and Banat 


\title{
Preliminary report on the excavation at Andornaktálya-Marinka in 2018
}

ZsOLT MESTER

Institute of Archaeological Sciences

Eötvös Loránd University

mester.zsolt@btk.elte.hu
FERENC CSERPÁK

independent researcher cserpakfeca@gmail.com

\section{Norbert FARAgó}

Institute of Archaeological Sciences

Eötvös Loránd University

norbert.farago@gmail.com

\begin{abstract}
Andornaktálya-Marinka is among the several Palaeolithic archaeological sites in the region of Eger, on the foothills of the Bükk Mountains, North-Eastern Hungary. It is situated on the top of a $234 \mathrm{~m}$ high elevation located between the villages Andornaktálya and Ostoros. The site was discovered in 2014 by Ferenc Cserpák. Surface collections yielded by several field surveys show two kinds of archaeological material: one is signified mostly by a bifacial-like industry made of quartz porphyry (metarhyolite), while the other one is abundant in blade-like pieces made of Silesian erratic flint. The main aim of the excavation carried out in summer 2018 was to obtain stratigraphic information about the position of the industries, as well as to characterize the quaternary sediments covering the hilltop. The artefacts unearthed in the five trenches occurred in a depth of 60 to $80 \mathrm{~cm}$ in a brown chernozem-like layer.
\end{abstract}

\section{Introduction}

The region of Eger belongs to the better-researched ones concerning the Palaeolithic period in Hungary. Apart from the field works and excavations conducted by professional colleagues and institutions, the forefront of the research has been always defined by the dedication and enthusiasm of amateur researchers. This was true during the 1940s, when the first and the most ambiguous site of the region, Eger-Kőporos was discovered by János Dancza and Ferenc Legányi. Legányi, and it was later verified and excavated by László Vértes. ${ }^{1}$ During the $1960 \mathrm{~s}$ and the 1970s, László Fodor has found new locations by field surveys linked to vineyard planting, ${ }^{2}$ and some of them were excavated by László Vértes and Viola T. Dobosi. ${ }^{3}$ In the 1980s and from the late 1990s onward, the number of recognized sites increased considerably thanks to the systematic prospections of György Salétli as well as Sándor Béres and Krisztián Zandler. ${ }^{4}$ Since 2002, systematic excavations are carried out in the region in the frame of a fruitful

1 VÉRTES 1951.

FODOR 1984.

Dobosi 1972; Dobosi 1976.

4 ZANDLER 2012. 
Polish-Hungarian collaboration. Until 2017, Andornaktálya-Zúgó, ${ }^{5}$ Egerszalók-Kővágó, ${ }^{6}$ EgerKöporos $^{7}$, and Andornaktálya-Gyilkos ${ }^{8}$ were excavated and published by the team led by Janusz K. Kozłowski and Zsolt Mester. In 2014, Ferenc Cserpák started field surveys in the region and discovered Andornaktálya-Marinka as a completely new site.

The region of Eger belongs to the "Bükkalja" geographic unit that constitutes the southern foothills of the Bükk Mountains, North-Eastern Hungary. Due to its geological history, this mountain and the foothills are rich in sources of knappable siliceous rocks. In 2017, a research project has been launched for studying the lithic resource management dynamics from the Middle Palaeolithic to the Middle Neolithic in Northern Hungary. ${ }^{9}$ The main aim is to study how human groups living in the region managed the exploitation of lithic resources in the changing natural and cultural environment. Based on its raw material composition and on its technological-typological properties, Andornaktálya-Marinka provided a good example for this problematic.

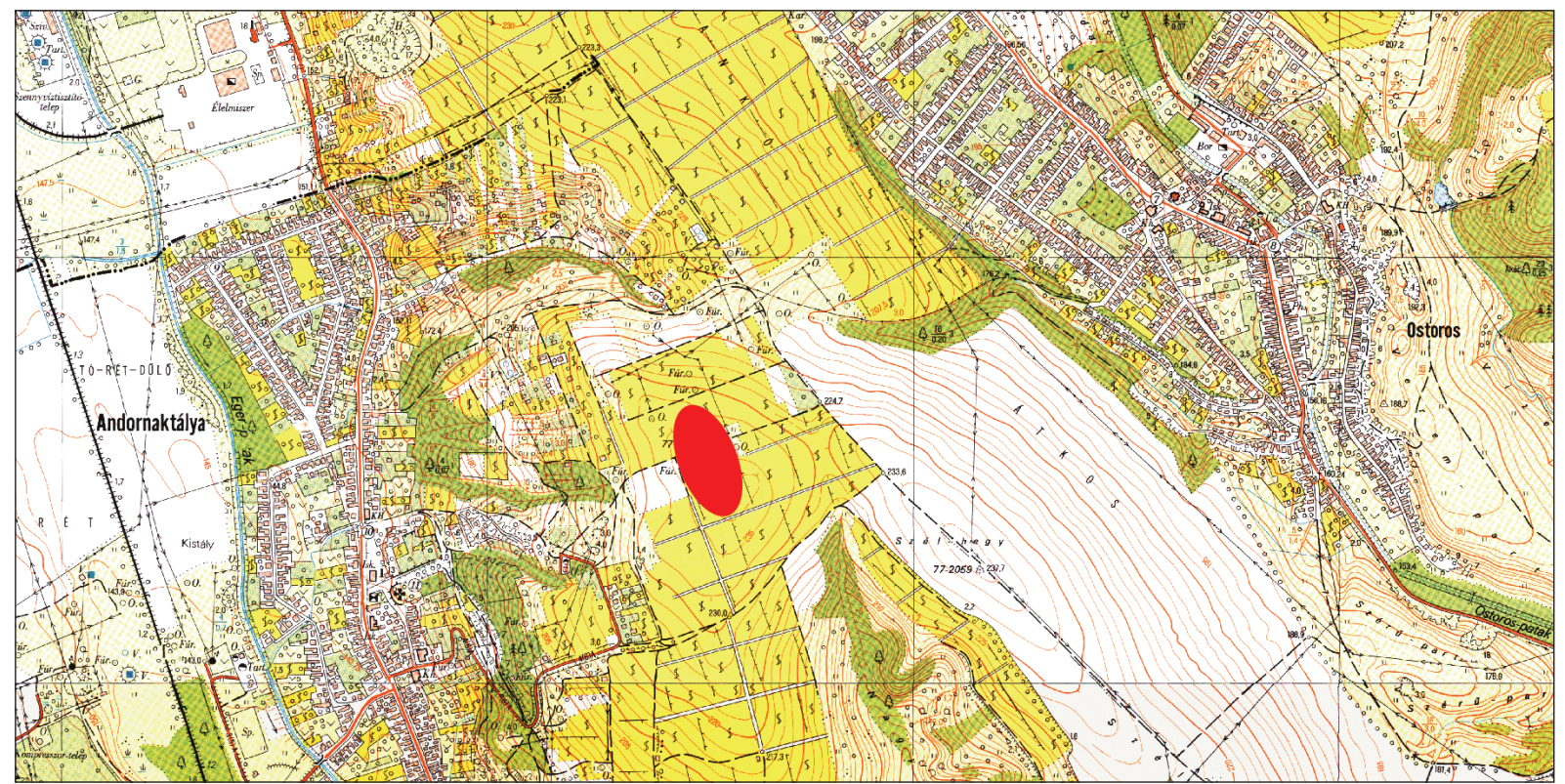

Fig. 1. Location of Andornaktálya-Marinka site on the topographic map.

\section{Site and material}

The discovery of the archaeological site and the first field collection can be dated to 2014. It is situated southeast of Eger at a distance of 7 kilometres, on the top of a $234 \mathrm{~m}$ high elevation located between the villages Andornaktálya and Ostoros (Fig. 1). A dirt road connecting the two settlements and winding between vineyards also divides the hilltop into two parts called Marinka (northern part) and Parti-szőlők (southern part). According to the results of field surveys, the site also yielded two kinds of archaeological material: one is signified mostly by a bifacial-like industry made of quartz porphyry (metarhyolite), while the other one is

5 KozŁOWsKi - Mester 2003-2004.

6 KozŁowsKi et al. 2009.

7 KozŁowski et al. 2012.

8 Mester 2013; MESTER et al. IN PRESS.

9 National Research, Development and Innovation Fund of Hungary, project K 124334. 
abundant in blade-like pieces made of Silesian erratic flint. Several field surveys have been carried out until 2018, which altogether resulted in 1270 pieces of knapped stones. Apart from these only a few undiagnostic ceramic sherds, daub fragments, and a polished stone tool were found at the southern part of the site, which indicates some human activities in a younger prehistoric period too.

\section{Excavation in 2018}

The excavation lasted for two weeks between $30^{\text {th }}$ July and $10^{\text {th }}$ August 2018. The main aim was to obtain stratigraphic information about the position of the industries, as well as to characterize the quaternary sediments covering the hilltop. A $5 \mathrm{~m}$ wide empty zone running parallel between the dirt road and the edge of the vineyard provided a chance to find an undisturbed situation. Along this zone, three trenches (S1, S2, S3 from west to east) were opened, $2 \times 1 \mathrm{~m}$ each and situated at a distance of $15 \mathrm{~m}$ from each other (Fig. 2). All of them were excavated to the bottom of the sequence, represented by the weathered layer of the rhyolite tuff of Miocene age reached a depth of about $150 \mathrm{~cm}$. In Trenches S2 and S3 (Fig. 3), the stratigraphy was the same, while the layers were less clearly visible in Trench S1. At the top of the stratigraphy, a 25-35 cm thick ploughing layer was observed suggesting that this zone was never planted by the vineyard. Under this agricultural layer, the sediments seemed to be undisturbed. From top to bottom clayey sediments of different colours succeeded: grey (5-10 cm thick), dark grey $(20-25 \mathrm{~cm})$, brownish grey $(25-30 \mathrm{~cm})$, and brown $(35-50 \mathrm{~cm})$. In the lowermost layer periglacial polygons were recognized.

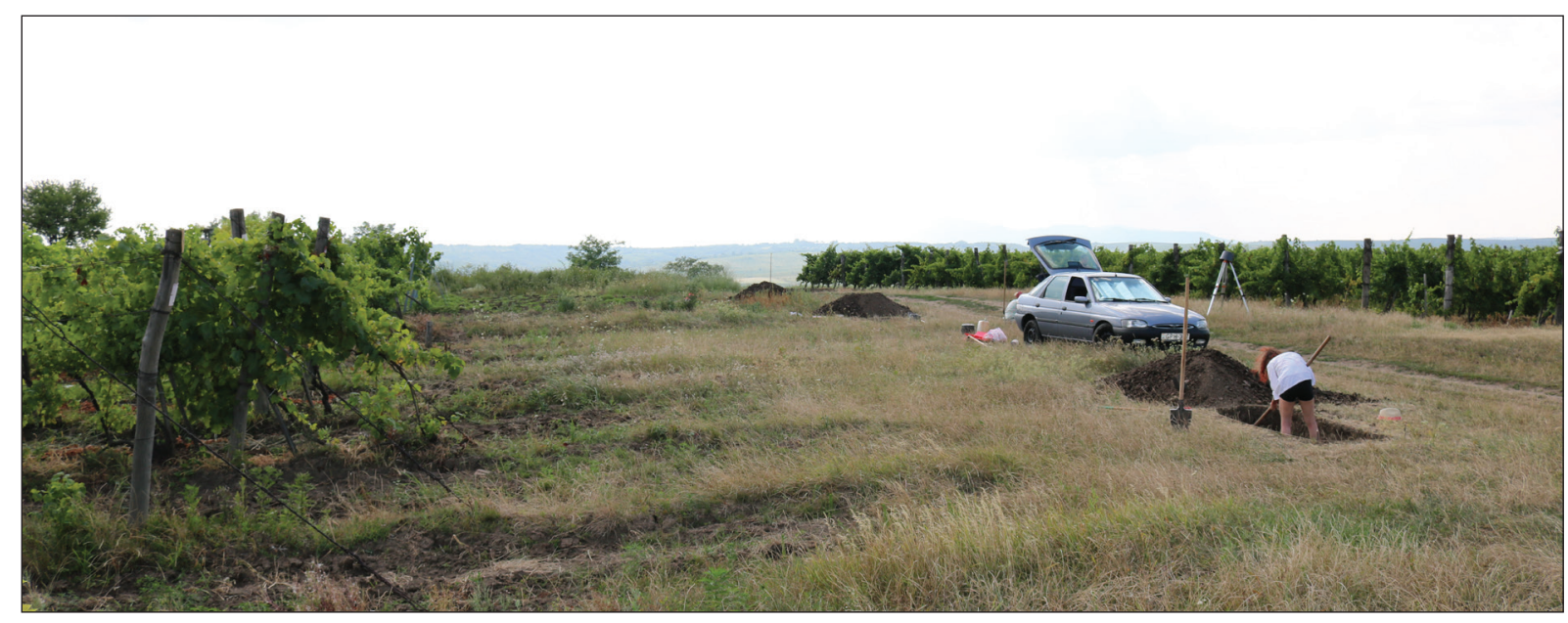

Fig. 2. The excavation area at the site with Trenches S1-S3 (photo by N. Faragó).

The first artefact came to light in Trench S2 at a depth of $60 \mathrm{~cm}$ from the actual surface. Altogether 12 pieces were found in this trench between 60 and $80 \mathrm{~cm}$ in depth. Trenches S1 and S3 were poor in finds; some small flakes occurred at the same depth as in Trench S2. For confirming this stratigraphic position of the artefacts, two more trenches were opened: $\mathrm{S} 4(2 \times 1 \mathrm{~m})$ between S1 and S2 as well as S5 $(2 \times 2 \mathrm{~m})$ to the east from S3, in accordance with Ferenc Cserpák's field observations about the distribution of the first finds. Despite the expectations, S4 yielded only two stray pieces, while S5 proved to be the most abundant in lithic finds, among which a characteristic Keilmesser-like bifacial tool made of quartz porphyry (metarhyolite) came to light (Fig. 4). 


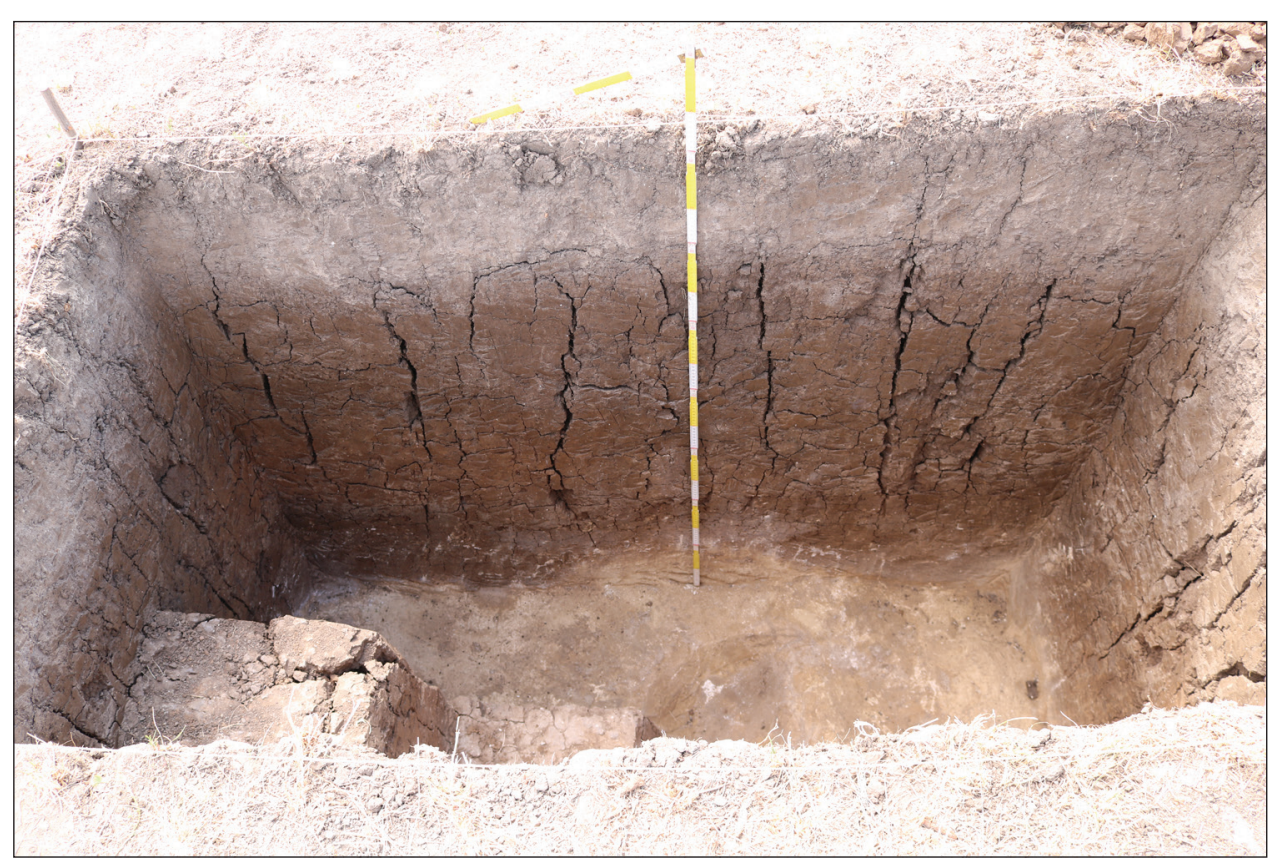

Fig. 3. The stratigraphic sequence of Trench S3 (photo by Zs. Mester).

Altogether 36 pieces were recorded in the five trenches, all of them occurred in a depth of 60 to $80 \mathrm{~cm}$ in the brown chernozem-like layer. The archaeological evaluation is still in progress, but according to the preliminary information all but one pieces were made of quartz porphyry (metarhyolite) and have a general Middle Palaeolithic nature. During the excavation Anna Dobos geomorphologist from the Eszterházy Károly University, Eger, Tomasz Kalicki and Marcin Frąnczek geomorphologists from the Jan Kochanowski University, Kielce Poland, studied the stratigraphic sequences and made samplings for sediment analyses and OSL dating from Trenches S2 and S3. Hopefully, these analyses will contribute to better understand the site formation and the chronological position of the human occupations.

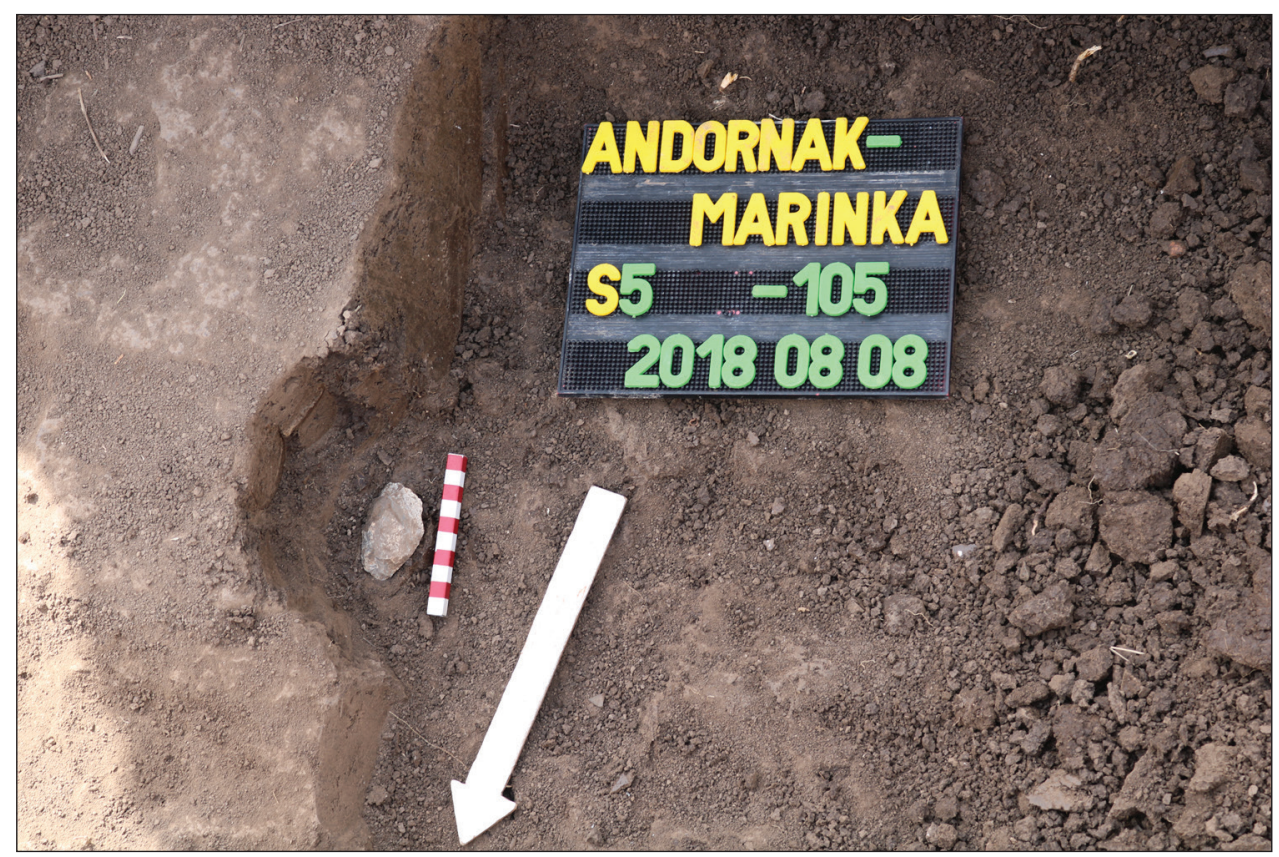

Fig. 4. The Keilmesser-like bifacial tool found in situ at Trench S5 (photo by N. Faragó). 


\section{Conclusion}

Andornaktálya-Marinka is among the several Paleolithic archaeological sites in the region of Eger, which are known thanks to the interests of amateur researchers, and which are explored thanks to the collaboration of colleagues coming from different scientific fields and institutions. Although its full evaluation is still in progress, its geographical situation and archaeological material on one side fit well into the wider picture of the Palaeolithic of the region. Since the excavation area overlaps the northern part of the site, the observed stratigraphic position of the artefacts concerns the bifacial industry. Further investigations are needed at the southern part of the site for clarifying the stratigraphic context of the younger industry. Detailed technological and typological analyses will shed light on the archaeological character of this latter.

\section{Acknowledgement}

We are grateful to the Dobó István Castle Museum, Eger, and especially to Mónika Gutay and Csaba Bálint for helping the realization of the excavation. Project no. 124334 has been implemented with the support provided from the National Research, Development and Innovation Fund of Hungary, financed under the K funding scheme.

\section{References}

Doвosi, V. T. 1972: Mesolithische Fundorte in Ungarn. Alba Regia 12 (1971), 39-60.

Dobosi, V. T. 1976: Prehistoric settlement at Demjén-Hegyeskőbérc. Folia Archareologica 27, 9-40.

FoDOR, L. 1984: Néhány őskori lelőhely Eger környékén (Einige prähistorische Fundstellen in der Umgebung von Eger). Agria - Az Egri Múzeum Évkönyve 20, 73-116.

KozŁowski, J. K. - Mester, Zs. 2003-2004: Un nouveau site du Paléolithique supérieur dans la région d'Eger (nord-est de la Hongrie). Praehistoria 4-5, 109-140.

KozŁowski, J. K. - Mester, Zs. - Zandler, K. - Budek, A. - Kalicki, T. - Moskal, M. - Ringer, Á. 2009: Le Paléolithique moyen et supérieur de la Hongrie du nord: nouvelles investigations dans la région d'Eger. L'Anthropologie 113, 399-453.

KozŁowski, J. K. - Mester, Zs. - Budek, A. - Kalicki, T. - Moskal-del Hoyo, M. - Zandler, K. BÉRES, S. 2012: La mise en valeur d'un ancien site éponyme: Eger-Kőporos dans le Paléolithique moyen et supérieur de la Hongrie du nord. L'Anthropologie 116, 405-465.

Mester, Zs. 2013: Excavation at a new Upper Palaeolithic site of the Eger region (Northern Hungary). Dissertationes Archaeologicae 3/1, 121-128.

Mester, Zs. - KozŁowski, J. K. - Kalicki, T. - Dobos, A. - Frąnczek, M. - Zandler, K. - Gutay, M. Béres, S. - Cserpák, F. IN press: Nouveaux assemblages du Paléolithique supérieur ancien en Hongrie du nord dans le contexte de l'hypothèse du Couloir danubien. L'Anthropologie.

VÉRTES, L. 1951: Mesolititcheskiye nakhodki na verchinie gory Kioporoch pri g. Eger (Vengriya) (Die mesolithische Fundstätte von Eger). Acta Archaeologica Academiae Scientiarum Hungaricae 1, 153-190.

ZANDLER, K. 2012: A paleolitikum kőiparai Eger környékén. Gesta 11, 3-54. 
